\title{
APLIKASI PENCARIAN KANTOR POLISI MENGGUNAKAN METODE DIJKSTRA BERBASIS MOBILE COMPUTING
}

\author{
Alim Hardiansyah ${ }^{1}$, Darmin $^{2}$, Ravie Kurnia Laday ${ }^{3}$ \\ alimhardiansyah@ista.ac.id, darmin@ista.ac.id, Raviekı@ista.com \\ Institut Sains dan Teknologi Al-Kamal
}

\begin{abstract}
Abstrak, Kota Tangerang merupakan salah satu kota yang berbatasan langsung dengan kota Jakarta. Kota ini mempunyai beberapa permasalahan salah satunya dalam hal tindak kejahatan yang terus naik setiap tahunnya. Tindak kejahatan di kota tangerang pada tahun 2018 telah terjadi sebanyak 6.211 kasus dengan crime clock 2 jam 20 menit 15 detik. Disamping itu kota ini juga minim petunjuk lokasi kantor polisi yang membuat kesan bahwa pencarian letak kantor polisi cukup sulit. Sistem informasi mengenai letak kantor polisi dengan menggunakan algoritma Dijkstra didalamnya dibutuhkan untuk membantu masyarakat dalam menentukan lokasi kantor polisi yang terdekat dari tempat mereka berada, sehingga didapat jarak terpendek. Metode pengembangan sistem menggunakan metode Spiral yang terdiri dari perencanaan, analisis resiko, produk rekayasa dan evaluasi pelanggan. Sistem ini dibangun dengan bahasa pemprograman Java dan XML. Rancangan aplikasi ini menggunakan UML. Sistem ini telah diuji dengan metode blackbox serta dengan pendekatan usability dan berhasil memberikan aplikasi tentang sistem informasi jarak terpendek dan informasi prosedur SKCK sesuai kebutuhan pengguna.
\end{abstract}

Kata kunci : Kantor Polisi, Dijkstra, Mobile computing

\section{PENDAHULUAN}

Tindak kejahatan di Indonesia semakin meningkat, terbukti dari hasil servei BPS (Badan Pusat Statistik) diperoleh kenaikan sebesar $6 \%$ tiap tahunnya ${ }^{[1]}$. Kota tangerang memiliki tindak kejahatan yang tidak sedikit yaitu sebanyak 6.211 kasus dengan crime clock 2 jam 20 menit 15 detik setiap harinya. Oleh karena itu, dapat disimpulkan bahwa tangerang termasuk kota yang belum aman terhadap tindak kejahatan. Kota tangerang sendiri memiliki 13 kecamatan, yang semestinya dalam 1 kecamatan mempunyai 1 polsek terdekat, tetapi dari hasil observasi hanya terdapat 8 polsek. Jumlah polsek yang sedikit ini tentu berpengaruh terhadap meningkatnya tindak kejahatan. Menurut Iptu Umi (Kasubag Pers) ada persoalan rumit yang menghinggapi masyarakat terkait minimnya petunjuk lokasi kantor polisi di jalan yang membuat kesan bahwa mencari lokasi kantor polisi di kota tangerang sangat sulit. Dari hasil observasi penulis bermaksud mengembangkan sebuah aplikasi dalam menemukan lokasi kantor polisi terdekat dengan memanfaatkan teknologi smartphone dengan sistem operasi Android yang didukung oleh penggunaan peta dalam Google Maps.

Tujuan penelitian ini yaitu merancang Sistem Informasi Geografis Kantor Polisi Di Kota Tangerang pada perangkat mobile yang bersifat local database dengan sistem operasi Android serta penerapan metode Dijkstra untuk mencari lokasi terdekat.

Metodologi yang digunakan untuk pengembangan perangkat lunak adalah teknik Spiral serta menggunakan perancangan berorientasi objek yang mana merupakan suatu cara bagaimana sistem perangkat lunak dibangun melalui pendekatan objek secara sistematis. Guna mengidentifikasi sistem yang sesuai dengan kebutuhan user serta menghasilkan perangkat lunak yang baik, maka analisis dengan pemodelan Unified Modeling Language (UML).

\section{METODOOGI ALGORITMA DIJKSTA}

Setelah mengumpulkan data kantor polisi satuan wilayah kota tangerang, selanjutnya membuat sebuah pemodelan graf yang dapat merepresentasikan jarak antara polsek terdekat terlihat pada Gambar 1. 


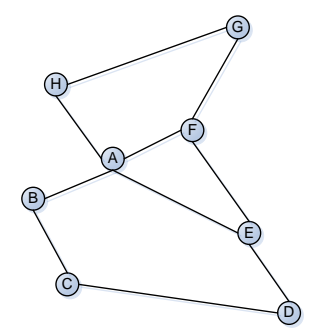

Gambar 1 Graf peta kantor polisi

Dari gambar 1 diatas mengenai pemodelan graf, dapat diambil sebuah contoh kasus misalkan seseorang yang hendak menempuh perjalanan dari Polsek Tangerang ke Polsek Ciledug (pada graf dinotasikan dari node A ke node $D$ ) seseorang tersebut menginginkan jarak terpendek yang ingin dilalui dapat dilihat pada Gambar 2.

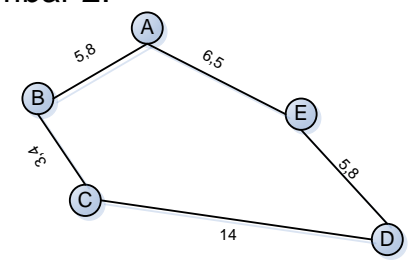

Gambar 2 Graf sederhana sebagai sampel

Berikut langkah-langkahnya:
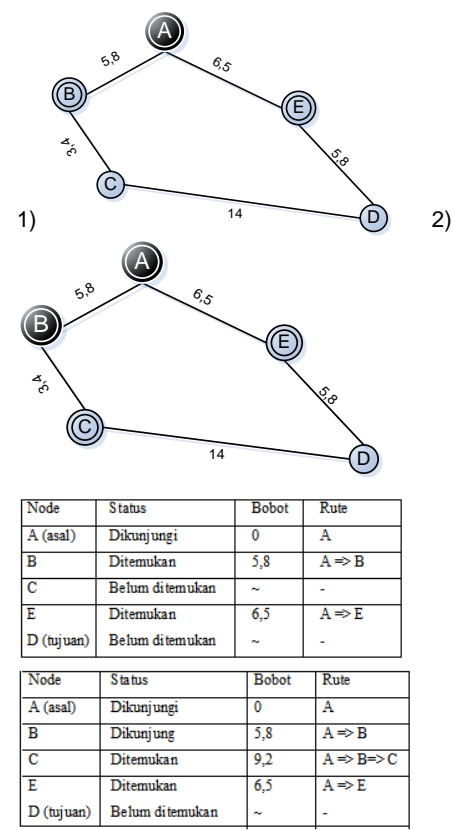

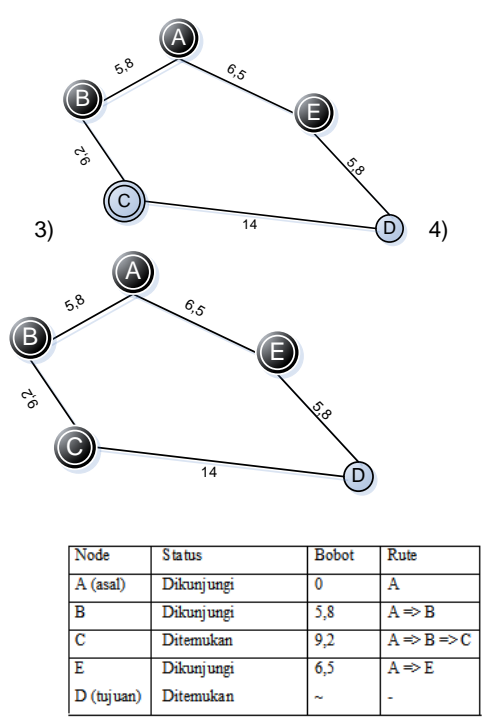

Node $C$ dengan bobot 9,2 dan node $D$ dengan bobot 12,3 maka dihasilkan node $\mathrm{C}$ sebagai bobot akumulasi terkecil. Kemudian sistem akan mengunjungi node $\mathrm{C}$.

Karena node $D$ sebagai node tujuan, maka pencarian dihentikan. Dengan demikian rute dengan bobot terkecil yang dapat dicapai ke node $D$ yaitu $A=>E \Rightarrow D=12,3$ dibandingkan dengan rute $A=>B \Rightarrow C=>D=23,2$

\section{PEMBAHASAAN}

Sesuai dengan metode pengembangan sistem perangkat lunak Spiral, maka tahapan yang dilakukan yaitu : perencanaan, analisis resiko, produk rekayasa dan evaluasi pelanggan[2].

Use Case Diagram

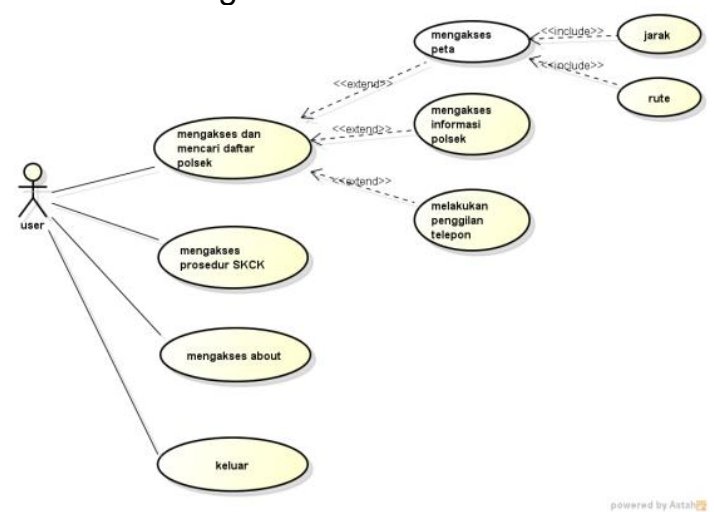

Gambar 3. Use Case Diagram

Gambar 3. diatas menjelaskan tentang Use Case Diagram, dimana user dapat mengakses menu-menu yang ada di dalam aplikasi yaitu daftar polsek, SKCK, about dan keluar. Penjelasan terkait menu di aplikasi SIG dapat dilihat pada tabel 1 .

Tabel 1 Definisi use case

\begin{tabular}{|l|l|l|}
\hline No & Use case & Deskripsi \\
\hline
\end{tabular}




\begin{tabular}{|l|l|l|}
\hline 1 & $\begin{array}{l}\text { Mengakses } \\
\text { dan } \\
\text { mencari } \\
\text { daftar } \\
\text { polsek }\end{array}$ & $\begin{array}{l}\text { Merupakan } \\
\text { proses dimana } \\
\text { user dapat } \\
\text { mengakses } \\
\text { menu daftar } \\
\text { polsek dan } \\
\text { melihat } \\
\text { polsek-polsek } \\
\text { yang ada di } \\
\text { tangerang } \\
\text { dalam aplikasi. }\end{array}$ \\
\hline 2 & $\begin{array}{l}\text { Mengakses } \\
\text { prosedur } \\
\text { SKCK }\end{array}$ & $\begin{array}{l}\text { Merupakan } \\
\text { proses dimana } \\
\text { user dapat } \\
\text { mengakses } \\
\text { menu } \\
\text { prosedur } \\
\text { SKCK. }\end{array}$ \\
\hline 3 & $\begin{array}{l}\text { Mengakses } \\
\text { peta }\end{array}$ & $\begin{array}{l}\text { Merupakan } \\
\text { proses dimana } \\
\text { user dapat } \\
\text { melihat peta } \\
\text { lokasi dari } \\
\text { kantor polisi. } \\
\text { datas mengenai }\end{array}$ \\
\hline
\end{tabular}

Berdasarkan Tabel 1 diatas mengenai definisi use case dijelaskan tentang mengakses menu-menu yang ada di dalam aplikasi SIG, seperti mengakses dan melihat daftar polsek, mengakses prosedur SKCK,dan peta.

\section{Scenario diagram}

Scenario diagram berfungsi untuk menjelaskan lebih detail dari penggambaran use case diagram pada Gambar 3 diatas.

1. Use case mengakses daftar polsek

Interaksi antara aktor dengan use case mengakses daftar polsek dijelaskan dalam use case scenario berikut:

Tabel 2. Scenario Use case mengakses daftar polsek

\begin{tabular}{|l|l|}
\hline Aksi Aktor & Reaksi Sistem \\
\hline $\begin{array}{l}\text { Memilih } \\
\text { menu daftar } \\
\text { polsek pada } \\
\text { halaman } \\
\text { home }\end{array}$ & $\begin{array}{l}\text { Menampilkan } \\
\text { daftar nama- } \\
\text { nama polsek }\end{array}$ \\
\hline $\begin{array}{l}\text { Memilih } \\
\text { salah satu } \\
\text { nama polsek }\end{array}$ & $\begin{array}{l}\text { Menampilkan } \\
\text { informasi } \\
\text { terkait polsek }\end{array}$ \\
\hline
\end{tabular}

Tabel 2. diatas menjelaskan interaksi yang terjadi antara aktor dan sistem daftar polsek. Jika aktor memilih menu daftar polsek pada halaman home maka sistem akan langsung menampilkan data polsek. Kemudian aktor memilih salah satu polsek dan sistem menampilkan informasi terkait.

\section{Use case mengakses prosedur SKCK}

Interaksi antara aktor dengan use case mengakses prosedur SKCK dijelaskan dalam use case scenario yaitu jika aktor memilih menu prosedur SKCK pada halaman home maka sistem akan langsung menampilkan informasi pembuatan SKCK.

3. Use case mengakses peta

Interaksi antara aktor dengan use case mengakses peta dijelaskan dalam use case scenario berikut:

Tabel 4. Scenario Use case mengakses peta

\begin{tabular}{|l|l|}
\hline Aksi Aktor & Reaksi Sisten \\
\hline $\begin{array}{l}\text { Memilih } \\
\text { menu daftar } \\
\text { polsek pada } \\
\text { halaman } \\
\text { home }\end{array}$ & $\begin{array}{l}\text { Menampilkan } \\
\text { daftar nama- } \\
\text { nama polsek }\end{array}$ \\
\hline $\begin{array}{l}\text { Memilih } \\
\text { salah satu } \\
\text { polsek }\end{array}$ & $\begin{array}{l}\text { Menampilkan } \\
\text { informasi } \\
\text { polsek, peta, } \\
\text { dan call }\end{array}$ \\
\hline
\end{tabular}

Tabel 4 diatas menjelaskan interaksi yang terjadi antara aktor dan sistem. Jika aktor memilih menu daftar polsek pada halaman home maka sistem menampilkan daftar nama-nama polsek lalu akor memilih slah satu polsek dan sistem menampilkan informasi polsek, peta, dan call. Kemudian aktor memilih peta, sistem langsung menampilkan peta lokasi polsek.

\section{Activity Diagram}

Jika use case scenario menjelaskan sistem secara tekstual maka dengan activity diagram akan dijelaskan secara visual lalu dijelaskan kembali menggunakan uraian workflow.

1. Activity Diagram mengakses daftar polsek

Activity yang direncanakan pada sistem daftar polsek adalah:

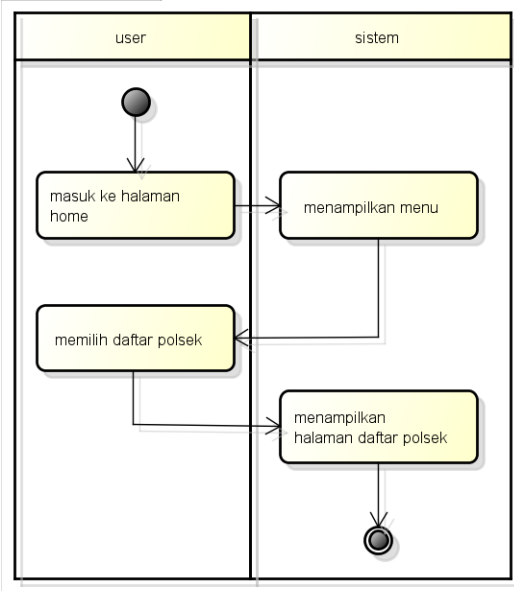

Gambar 4. Activity Diagram mengakses daftar polsek 
Gambar 4. diatas menjelaskan tentang Activity Diagram mengakses daftar polsek, dimana langkah awal user masuk ke halaman home lalu sistem menampilkan menu setelah itu user memilih daftar polsek kemudian sistem menampilkan halaman daftar polsek.

2. Activity Diagram mengakses peta lokasi

Activity yang direncanakan pada sistem mengakses peta lokasi adalah:

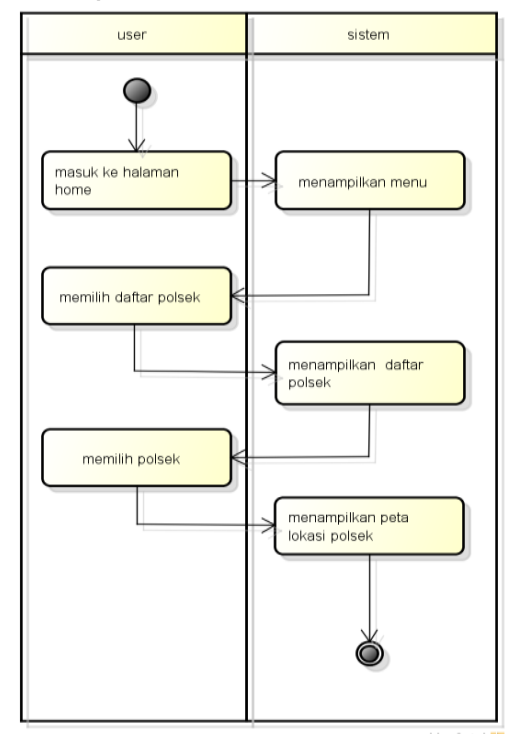

Gambar 5. Activity Diagram mengakses peta lokasi

Gambar 5 menjelaskan tentang Activity Diagram mengakses peta lokasi, langkah pertama user masuk ke halaman home setelah itu sistem menampilkan menu lalu user memilih daftar polsek kemudian sistem menampilkan nama-nama polsek, lalu user memilih salah satu polsek dan sistem menampilkan peta lokasi polsek.

3. Activity Diagram mengakses prosedur SKCK Activity yang direncanakan pada sistem prosedur SKCK adalah:

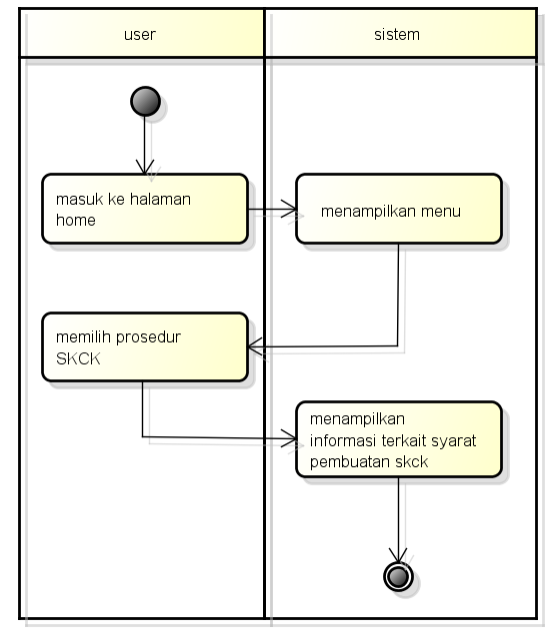

\section{Gambar 6 Activity Diagram mengakses} prosedur SKCK

Gambar 6 menjelaskan tentang Activity Diagram prosedur SKCK, langkah pertama user masuk ke halaman home setelah itu sistem menampilkan menu lalu user memilih prosedur SKCK kemudian sistem menampilkan prosedur pembuatan SKCK.

\section{Class Diagram}

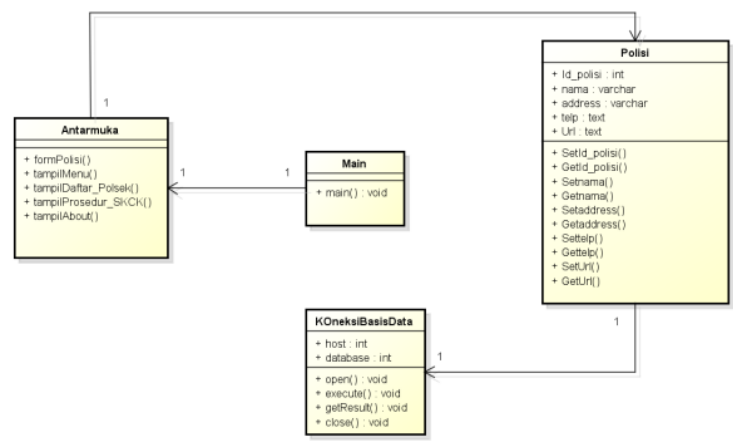

Gambar 7. Class Diagram SIG

Gambar 7. diatas adalah class diagram dari aplikasi SIG yang terdiri dari koneksi basis data, main, polisi dan antarmuka, dimana saling terhubung satu sama lain untuk lebih lengkapnya dapat dilihat pada tabel 5 . Keterangan class diagram :

Tabel 5. Class diagram

\begin{tabular}{|l|l|}
\hline Nama Kelas & Keterangan \\
\hline Main & $\begin{array}{l}\text { Merupakan kelas } \\
\text { main }\end{array}$ \\
\hline Antar Muka & $\begin{array}{l}\text { Merupakan kelas } \\
\text { yang menangani } \\
\text { tampilan }\end{array}$ \\
\hline Polisi & $\begin{array}{l}\text { Merupakan kelas } \\
\text { data yang } \\
\text { digunakan untuk } \\
\text { memproses } \\
\text { segala } \\
\text { pengaksesan } \\
\text { terhadap menu } \\
\text { daftar polsek. }\end{array}$ \\
\hline Koneksi Basis & $\begin{array}{l}\text { Merupakan kelas } \\
\text { utilitas untuk } \\
\text { Data }\end{array}$ \\
& $\begin{array}{l}\text { koneksi kebasis } \\
\text { data dan } \\
\text { melakukan query }\end{array}$ \\
\hline
\end{tabular}

Tabel 5. diatas menjelaskan tentang kelas main, kelas antar muka, kelas polisi, dan kelas koneksi basis data.

Sequence diagram

Sequence diagram digunakan untuk menggambarkan interaksi antar objek didalam dan sekitar sistem yang berupa message yang digambarkan terhadap waktu. Sequence diagram terdiri antara dimensi 
vertical (waktu) dan horizontal (objek-objek yang terkait). Sequence diagram dari perancangan SIG ini adalah sebagai berikut: untuk ditampilkan dalam bentuk landscape. Berikut rancangan antarmuka :

1. Sequence diagram mengakses daftar polsek

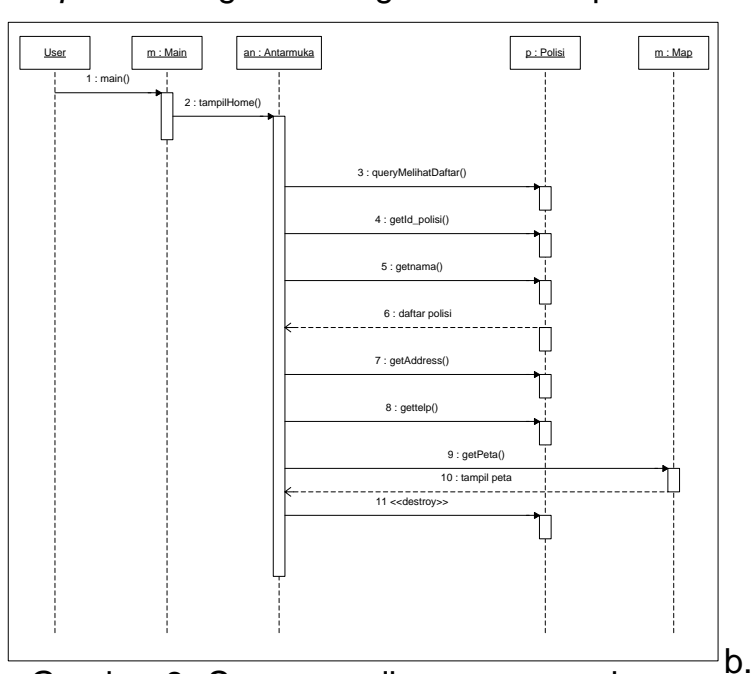

a. Tampilan menu utama

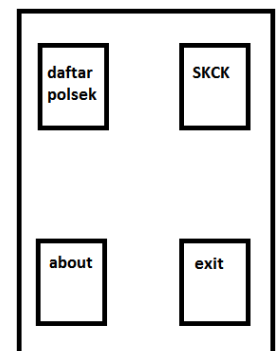

Gambar 10. Rancangan antarmuka menu utama

Gambar 10. adalah tampilan menu utama, yang berisikan menu-menu dalam aplikasi yaitu daftar polsek, prosedur SKCK, about dan Exit.

Gambar 8. Sequence diagram mengakses daftar polsek

Gambar 8. diatas menjelaskan interaksi antara aktor dan sistem dari daftar polsek yang digambarkan dengan sequence diagram. Langkah pertama user membuka aplikasi lalu sistem membuka tampilan home kemudian tampil proses lihat daftar polsek. Setelah itu sistem menampilkan menu polisi (list polisi) dan informasi polsek yang dipilih serta telpon dan peta lokasi.

2. Sequence diagram melihat prosedur SKCK

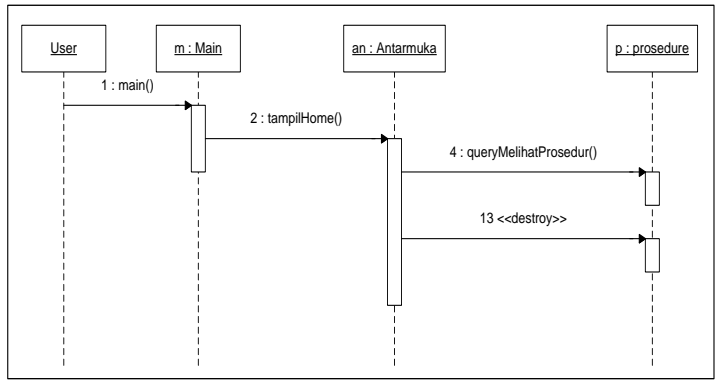

Gambar 9. Sequence diagram melihat prosedur SKCK

Gambar 9. diatas menjelaskan interaksi antara aktor dan sistem dari melihat prosedur SKCK yang digambarkan dengan sequence diagram, dimana langkah awal user membuka aplikasi lalu sistem membuka tampilan home. Kemudian sistem menampilkan menu prosedur SKCK yang berisikan informasi pembuatan SKCK.

\subsection{Perancangan Antarmuka}

Aplikasi ini dirancang untuk penggunaan secara portrait, sehingga hasil tidak cocok b. Tampilan daftar polsek

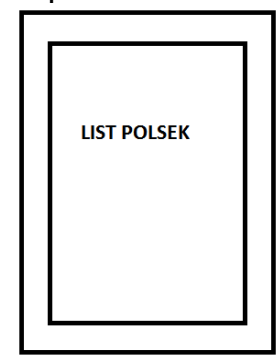

Gambar 11. Rancangan antarmuka daftar polsek

Pada Gambar 11. diatas adalah tampilan jika user memilih menu daftar polsek, dimana menu tersebut berisikan list-list nama polsek di kota Tangerang.

c. Tampilan prosedur SKCK

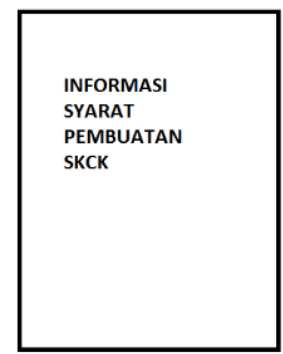

Gambar 12. Rancangan antarmuka menu prosedur SKCK

Pada Gambar 12. diatas adalah tampilan dari menu prosedur SKCK yang berisikan informasi syarat pembuatan SKCK.

d. Tampilan informasi polsek 


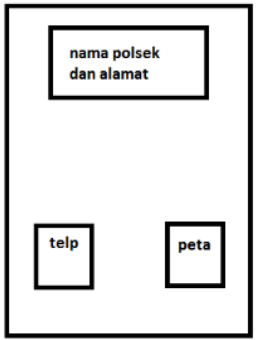

Gambar 13. Rancangan antarmuka informasi polsek

Gambar 13. diatas adalah tampilan jika user memilih menu daftar polsek, Ialu memilih polsek yang diinginkan kemudian tampil detai dari informasi polsek. Dimana informasi polsek berisikan tombol call/telp dan peta.

\section{IMPLEMENTASI DAN PENGUJIAN Implementasi Sistem}

Sebelum mengimplementasikan dan menjalankan Aplikasi Sistem Informasi Geografis ini, terlebih dahulu harus memasang komponen-komponen pendukung aplikasi pada komputer. Komponenkomponen tersebut dapat berupa perangkat keras (hardware) dan perangkat lunak (software) sehingga aplikasi tersebut dapat berjalan dengan baik.

\section{Kebutuhan Perangkat Keras}

Untuk dapat menjalankan Aplikasi SIG ini dibutuhkan perangkat keras (hardware) minimal dengan spesifikasi sebagai berikut:

Tabel 6. Kebutuhan Perangkat Keras

\begin{tabular}{|c|c|}
\hline $\begin{array}{l}\text { Perangkat } \\
\text { Keras }\end{array}$ & Spesifikasi \\
\hline Processor & $\begin{array}{l}\text { Intel Core i5- } \\
450 \mathrm{M}\end{array}$ \\
\hline VGA & $\begin{array}{ll}\text { Intel }(R) & H D \\
\text { Grapics } & \\
\end{array}$ \\
\hline Harddisk & $350 \mathrm{~GB}$ \\
\hline RAM & $2 \mathrm{~GB}$ \\
\hline $\begin{array}{l}\text { Smartphone } \\
\text { Android }\end{array}$ & $\begin{array}{l}\text { Lenovo A3500- } \\
\text { HV dengan } \\
\text { RAM } 1 \text { GB, OS } \\
\text { Android Jelly } \\
\text { Bean. }\end{array}$ \\
\hline
\end{tabular}

\section{Kebutuhan Perangkat Lunak}

Kebutuhan Perangkat Lunak (software) yang dibutuhkan untuk menjalankan Aplikasi SIG adalah sebagai berikut:

Tabel 7. Kebutuhan perangkat lunak

\begin{tabular}{|l|l|}
\hline Perangkat Lunak & Spesifikasi \\
\hline Sistem Operasi & $\begin{array}{l}\text { Windows } \\
\text { Ultimate }\end{array}$ \\
\hline Program Editor & ADT v21.1.0 \\
\hline $\begin{array}{l}\text { Program } \\
\text { Emulator }\end{array}$ & $\begin{array}{l}\text { Android Virtual } \\
\text { Device }\end{array}$ \\
\hline
\end{tabular}

\begin{tabular}{|l|l|}
\hline $\begin{array}{l}\text { Program } \\
\text { Database }\end{array}$ & SQLite \\
\hline $\begin{array}{l}\text { Program } \\
\text { Perancangan }\end{array}$ & Astah dan \\
\hline
\end{tabular}

\section{Implementasi Database}

Aplikasi ini memiliki database dengan tujuh tabel mengikuti tahap perancangan tanpa ada perubahan. Database untuk aplikasi ini dibuat dengan bantuan SQLite yang dapat digunakan untuk sistem operasi android.

\section{Implementasi Antarmuka}

Antarmuka dari aplikasi ini dibuat dengan bantuan Android Developer Tools. Antarmuka yang dibuat mengacu pada perancangan setiap activity diagram, berikut ini gambargambar dari implementasi antarmuka pada mobile berbasis Android :

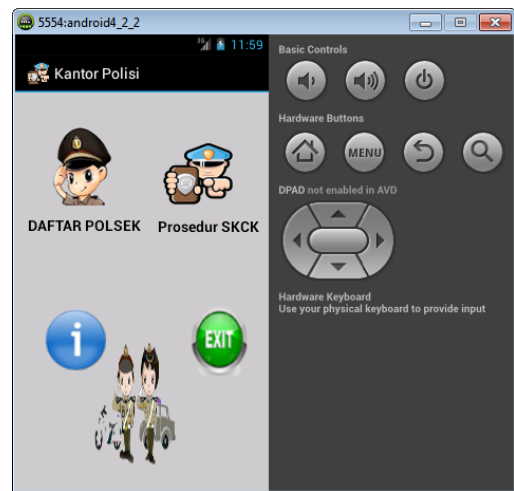

Gambar 12. Implementasi antarmuka halaman utama

Gambar 12. Implementasi mengacu pada rancangan antarmuka yang telah dibuat sebelumnya, halaman utama pada aplikasi ini hanya diletakkan empat icon yaitu daftar polsek, prosedur skck, about dan exit.

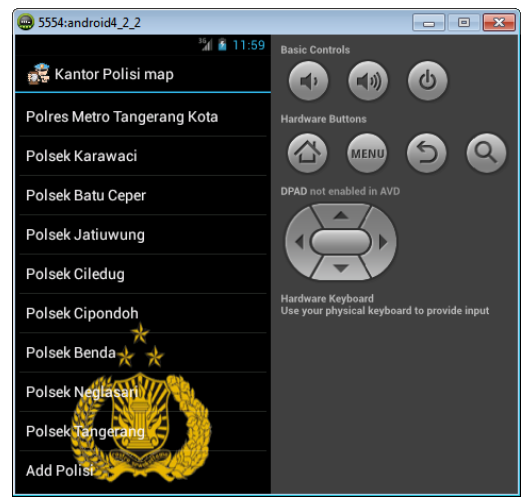

Gambar 13. Implementasi antarmuka Daftar Polsek

Pada Gambar 13. diatas menunjukan tampilan antarmuka setelah user memilih menu daftar polsek. Halaman daftar polsek berupa list-list daftar nama polsek. 


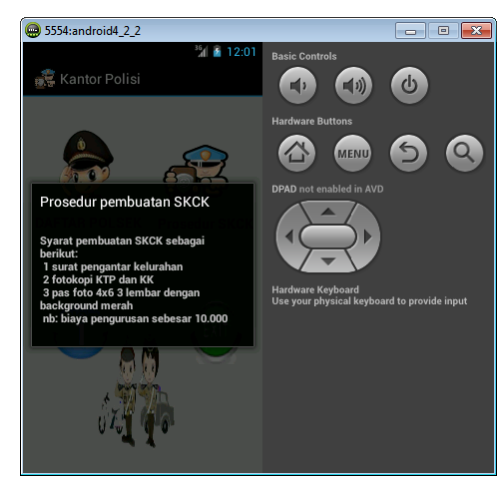

Gambar 14. Implementasi antarmuka prosedur SKCK

Gambar 14. diatas adalah tampilan jika user memilih menu prosedur SKCK, dimana menu tersebut berisikan informasi terkait syarat pembuatan SKCK.

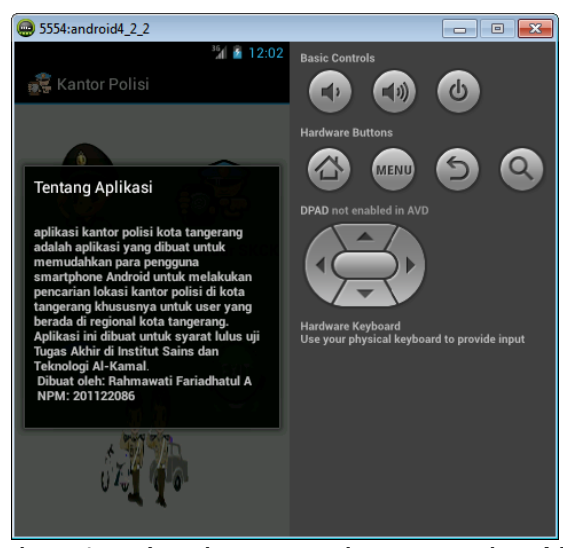

Gambar 15. Implementasi antarmuka About Gambar 15. diatas adalah tampilan jika user memilih menu about, dimana menu tersebut berisikan informasi terkait aplikasi dan pengembang.

Icon yang digunakan berukuran $100 \mathrm{x}$ 100 pixel. Desain antarmuka yang sederhana dari sebuah task, information hierarchy dan visual display membuat pengguna menjadi lebih mudah dalam mengoperasikan smartphone ${ }^{[3]}$. Gambar 4.2 merupakan halaman daftar polsek yang terdiri dari polsek tangerang kota, batu ceper, cipondoh dll. Warna teks adalah hitam sedangkan background berwarna abu. Warna hitam dipilih agar tulisan dapat dengan jelas terbaca oleh pengguna. Tampilan dibuat berupa list. Hal ini dilakukan agar menu dapat di navigasi dengan mudah oleh pengguna. Target user yang menggunakan aplikasi ini yaitu usia 17 tahun ke atas, dimana menjadi latar belakang dibuatnya menu prosedur SKCK pada gambar 15.

\section{Analisis Kegunaan}

Menurut Nielsen dan Loranger ada beberapa tolak ukur yang bisa dijadikan ukuran usability $^{[4]}$ diantaranya:
1. Succes rate

Tingkat kesuksesan pengguna menyelesaikan sebuah task.

2. The time a task requires waktu yang dibutuhkan pengguna untuk menyelesaikan task.

3. Error rate

Tingkat kesalahan yang dilakukan pengguna saat menyelesaikan task melalui rumus error rate seperti dibawah ini:

$$
E R=100 \%-\left(\frac{\text { Task Berhasil }}{\text { Total Task }}\right) \times 100 \%
$$

Selanjutnya dilakukan Pengukuran usability menggunakan adopsi kuesioner Software Usability Measurement Inventory (SUMI). Analisis dilakukan dengan pengujian yang secara objektif kepada pengguna yang telah menggunakan aplikasi SIG Kantor Polisi sebanyak 10 responden. Aplikasi ini dipasang pada perangkat smartphone android dengan versi dan merek yang berbeda-beda. Langkah awal usability testing ini adalah memberikan sejumlah task atau tugas yang sudah dipersiapkan sebelumnya kepada pengguna saat berinteraksi dengan sistem yang diuji. Task-task ini digunakan sebagai 'sarana interaksi' dalam pengukuran usability[5]. Beberapa task yang digunakan langsung berkaitan dengan repository diantaranya yaitu

1. Responden membuka aplikasi SIG

2. Responden membuka menu daftar polsek.

3. Responden membuka polsek yang dipilih pada menu daftar polsek.

4. Responden mengklik tombol direction untuk menampilkan peta

5. Responden membuka detail informasi dengan mengklik nama polsek

6. Responden membuka menu prosedur skck.

7. Responden membuka menu about.

Dari beberapa task diatas dapat dilakukan perhitungan error rate. Pengguna dilibatkan secara langsung terhadap aplikasi SIG. Tingkat kesalahan pengguna diamati dengan cara menghitung task yang tidak berhasil diselesaikan oleh pengguna ${ }^{6}$. Hasil dari perhitungan error rate pada task pengujian terdapat pada Tabel 4.2. Error rate pada aplikasi ini yaitu 4 error dengan nilai 12.5 $\%$ dan $25 \%$ artinya hanya dua task yang error dari 8 task yang diujikan.

Tabel 4.2 keberhasilan aplikasi

\begin{tabular}{|c|c|c|}
\hline $\begin{array}{c}\text { Peng } \\
\text { guna } \\
\mathrm{Ke}-\end{array}$ & Task Ke- & $\begin{array}{c}\text { Error } \\
\text { rate } \\
(\%)\end{array}$ \\
\hline
\end{tabular}




\begin{tabular}{|c|c|c|c|c|c|c|c|c|}
\hline & 1 & 2 & 3 & 4 & 5 & 6 & 7 & \\
\hline 1 & $\sqrt{ }$ & $\sqrt{ }$ & $\sqrt{ }$ & $\sqrt{ }$ & $\sqrt{ }$ & $\sqrt{ }$ & $\sqrt{ }$ & 0.0 \\
\hline 2 & $\sqrt{ }$ & $\sqrt{ }$ & $\sqrt{ }$ & $\sqrt{ }$ & $\sqrt{ }$ & $\sqrt{ }$ & $\sqrt{ }$ & 0.0 \\
\hline 3 & $\sqrt{ }$ & $\sqrt{ }$ & $\sqrt{ }$ & $\sqrt{ }$ & $\sqrt{ }$ & $\sqrt{ }$ & $\sqrt{ }$ & 0.0 \\
\hline 4 & $\sqrt{ }$ & $\sqrt{ }$ & $\sqrt{ }$ & $\sqrt{ }$ & $\sqrt{ }$ & $\sqrt{ }$ & $\sqrt{ }$ & 0.0 \\
\hline 5 & $\sqrt{ }$ & $\sqrt{ }$ & $\sqrt{ }$ & $\sqrt{ }$ & $\sqrt{ }$ & $\sqrt{ }$ & $\sqrt{ }$ & 0.0 \\
\hline 6 & $\sqrt{ }$ & $\sqrt{ }$ & $\sqrt{ }$ & $\sqrt{ }$ & $\sqrt{ }$ & $\sqrt{ }$ & $\sqrt{ }$ & 0.0 \\
\hline 7 & $\sqrt{ }$ & $\sqrt{ }$ & $\sqrt{ }$ & $\sqrt{ }$ & $\sqrt{ }$ & $\sqrt{ }$ & $\sqrt{ }$ & 0.0 \\
\hline 8 & $\sqrt{ }$ & $\sqrt{ }$ & $\sqrt{ }$ & $\sqrt{ }$ & $\mathrm{X}$ & $\sqrt{ }$ & $\sqrt{ }$ & $12,5 \%$ \\
\hline 9 & $\sqrt{ }$ & $\sqrt{ }$ & $\sqrt{ }$ & $\sqrt{ }$ & $\mathrm{X}$ & $\mathrm{X}$ & $\sqrt{ }$ & $25 \%$ \\
\hline 10 & $\sqrt{ }$ & $\sqrt{ }$ & $\sqrt{ }$ & $\sqrt{ }$ & $\mathrm{X}$ & $\sqrt{ }$ & $\sqrt{ }$ & $12,5 \%$ \\
\hline \multicolumn{7}{|c|}{ Rata-rata } \\
\hline \multicolumn{7}{|c|}{} \\
\hline \multicolumn{7}{|c|}{}
\end{tabular}

\section{Kuesioner SUMI}

Tahap selanjutnya responden diminta memberikan tanggapan terhadap setiap pertanyaan dari kuesioner SUMI. Skor yang digunakan untuk setiap tanggapan setuju, tidak tahu dan tidak setuju dengan kategori efektivitas, efisiensi dan kepuasan berupa penilaian dengan skala 0-100. Jumlah pertanyaan yang diberikan kepada responden terdiri dari 19 pertanyaan.

Skor akhir dari setiap kategori menggunakan median pada setiap nilai terurut yang diberikan oleh responden untuk mendapatkan hasil usability suatu

\section{PENUTUP}

Kesimpulan

Aplikasi Sistem Informasi Geografis Kantor Polisi Kota tangerang menggunakan algoritma dijkstra yang berfungsi untuk menampilkan peta lokasi dan mencari jarak terpendek dari posisi user. Selain itu pada aplikasi ini juga disediakan prosedur dalam pembuatan SKCK. Sistem menggunakan usability dengan ketentuan efektifitas, efisiensi dan kepuasan. Hasil dari usability menunjukan skor dari setiap kategori bernilai 100 sehingga dapat disimpulkan bahwa nilai berada diatas rata-rata ketentuan artinya aplikasi sudah layak digunakan.Sasaran pengguna untuk aplikasi ini pada rentang usia 17 tahun keatas.

\section{Saran}

Aplikasi yang dihasilkan dari penelitian ini masih memiliki beberapa kekurangan, oleh karena itu beberapa saran yang dapat menjadikan aplikasi ini lebih baik, yaitu :

1. Penambahan data sehingga informasi yang ditampilkan lebih mendetail lagi. aplikasi. Menurut ketentuan SUMI jika hasil pengukuran median kurang dari 50 berarti masih dibawah rata-rata. Terlihat pada Tabel 6 bahwa skor median dari setiap kategori berada diatas rata-rata ketentuan SUMI yaitu100, 100, dan 100 artinya usability pada prototype sistem ini sudah baik.

Tabel 4.3 Perhitungan skor hasil evaluasi SUMI

\begin{tabular}{|l|c|c|c|}
\hline \multirow{2}{*}{$\begin{array}{c}\text { Penggu } \\
\text { na Ke- }\end{array}$} & \multicolumn{3}{|c|}{ Total evaluasi SUMI } \\
\cline { 2 - 4 } & Efektivitas & $\begin{array}{c}\text { Efisien } \\
\text { si }\end{array}$ & $\begin{array}{c}\text { Kepua } \\
\text { san }\end{array}$ \\
\hline 1 & 100 & 100 & 100 \\
\hline 2 & 100 & 100 & 100 \\
\hline 3 & 100 & 100 & 100 \\
\hline 4 & 100 & 100 & 100 \\
\hline 5 & 87 & 100 & 89 \\
\hline 6 & 75 & 50 & 78 \\
\hline 7 & 100 & 100 & 100 \\
\hline 8 & 100 & 100 & 100 \\
\hline 9 & 100 & 100 & 100 \\
\hline 10 & 100 & 100 & 100 \\
\hline Median & 100 & 100 & 100 \\
\hline
\end{tabular}

2. Penggunaan fitur GPS untuk menentukan lokasi user berada.

\section{DAFTAR PUSTAKA}

[1] [BPS] Badan Pusat Statistik. 2014. Jumlah Tindak Pidana Menurut Kepolisian Daerah, 2000-2004. Jakarta(ID) : BPS.

[2] Prahasta, Edy. 2009. SIG Konsep-konsep dasar. Informatika. Bandung.

[3] Choi JH, Lee HJ. 2012. Facets of simplicity for the smartphone interface: A structural model. International Journal HumanComputer Studies 70 (2012):129-142.

[4] Nielsen J, Loranger H. 2006. Prioritizing Web Usability. Berkeley: New Riders.

[5] Sastramihardja H, Hapsari IN, Neri IA. 2008. Pengukuran Usability Dengan Sarana Task Model Dalam User Center Software Development. Jurnal Penelitian dan Pengembangan Telekomunikasi. Vol. 13 No.2

[6] Hamidah. 2013. Pengembangan Situs PTN Menggunakan Usability Engineering Dan Evaluasi Usability Dengan Kuesioner SUMI. [Skripsi]. Bogor (ID): Institut Pertanian Bogor. 